\title{
THE SHARE OF TISSUES IN PIG CARCASS SIDES OF AUTOCHTHONOUS BREEDS DEPENDING ON THE BODY MASS AND SEX
}

\author{
M. Petrović ${ }^{1}$ Č. Radović ${ }^{2}$, M. Mijatović ${ }^{1}$, D. Radojković ${ }^{1}$, N. Stanišić ${ }^{2}$, \\ N. Parunović ${ }^{3}$ \\ ${ }^{1}$ Faculty of Agriculture, 11080, Belgrade - Zemun, Republic of Serbia \\ ${ }^{2}$ Institute for Animal Husbandry, 11080, Belgrade-Zemun, Republic of Serbia \\ ${ }^{3}$ Institute of Meat Hygiene and Technology, 11000, Belgrade, Republic of Serbia \\ Corresponding author: milica@agrif.bg.ac.rs \\ Invited paper
}

Abstract: Objective of this paper was to determine the distribution of tissues in four major carcass side parts from fatteners of Swallow-Belly Mangalitsa and Moravka breeds. The study included 42 animals (male castrated and female pigs) of Swallow-Belly Mangalitsa strain (LM, $n=19)$ and Moravka $(M, n=23)$. Animals were kept and reared in the same farm conditions with free ranges. During fattening, animals were fed two complete mixtures containing 15 and $13 \%$ crude proteins. Dissection of left carcass sides and calculation of the meat percentage were carried out according to EU reference method (EC, No.3127/94). Obtained data was processed using GLM procedure of the software package SAS 9.1.3 (SAS Inst.Inc., 2002-2003). Pre-slaughter body mass influenced variation of the mass of warm and cooled carcass sides $(\mathrm{P}<.0001)$. Pre-slaughter body mass of SBM and $\mathrm{M}$ had impact on variation of the subcutaneous fat tissue and skin in the thigh and shoulder, and on bone tissue in the shoulder. Fatteners of Moravka breed had higher average mass of back-loin part of the carcass sides $(\mathrm{P}<0.01)$ and mass of subcutaneous fat tissue including the skin $(\mathrm{P}<0.05)$ compared to Swallow-Belly Mangalitsa. Share of muscle tissue of this carcass part in total mass of muscle tissue in all four carcass side parts was higher in Moravka breed pigs $(+2.18 \%$, $\mathrm{P}<0.01$ ). Male castrated pigs had lower values of average mass of the thigh/leg $(\mathrm{P}<0.05)$, lower values of muscle tissue mass in the thigh/leg $(\mathrm{P}<0.01)$ and higher share of bone tissue $(\mathrm{P}<0.05)$ compared to female pigs. In the belly-rib part, castrates had less intermuscular fat tissue $(\mathrm{P}<0.05)$ and bone tissue $(\mathrm{P}<0.05)$ than female pigs.

Key words: pig, autochthonous breeds, Swallow-Belly Mangalitsa, Moravka, carcass side 


\section{Introduction}

In recent years, there has been increasing interest in autochthonous breeds, and not only in regard to their gene preservation but also in their meat products manufactured in traditional way. Mangalitsa is typical meat bread which contains approx. 30-35\% of meat in carcass sides (Egerszegi et al., 2003; Kralik and Petričević, 2001, Petrović et al., 2009; 2010). Moravka is a breed of combined production abilities, with more meat contained in the carcass side and less fat, compared to Mangalitsa (Petrović et al., 2009, 2010). Today, autochthonous breeds are reared in the open system or farm conditions, and they are fed in traditional way or by using complete mixtures.

Objective of this study was to determine the distribution of tissues in carcass sides and four major carcass side parts (thigh/leg, shoulder, back-loin and belly-rib parts) in fatteners of Swallow-Belly Mangalitsa and Moravka breeds, depending on the pre-slaughter body mass and animal sex.

\section{Materials and Methods}

The study included 42 animals (male castrated and female animals) of the Swallow-Belly Mangalitsa strain (LM, $n=19)$ and Moravka breed (M, $n=23$ ). Animals of both breeds were born, reared and slaughtered in the same herd (Institute for Animal husbandry, Belgrade-Zemun). Animals were kept and reared in farm conditions with free ranges. Surface of the open/outside area was $110 \mathrm{~m}^{2}$ and sheltered area $40 \mathrm{~m}^{2}$. There were 10 animals in the group and each animal had $1,5 \mathrm{~m}^{2}$ of area. During fattening animals were fed two complete mixtures consisting of corn silage, livestock flour, soybean meal, sunflower meal, synthetic lysine mineral feeds and pre-mixture. The first mixture contained in average $15 \%$ and the second $13 \%$ of crude proteins. Water was ad libitum. Fattening lasted until animals reached different body masses, so the first group $\left(\mathrm{G}_{1}\right)$ had pre-slaughter body masses in range from 91 to 100 , and the second group $\left(\mathrm{G}_{2}\right)$ from 101 to 120 kilograms. Linear measures on warm carcass sides were taken on slaughter line. Dissection of left carcass sides and calculation of meat percentage were carried out according to EU reference method (EC, No.3127/94) explained by Walstra and Merkus (1996).

Obtained data was processed by using the GLM procedure of the software package "SAS/STAT" (SAS Inst.Inc., 2002-2003). The breed of fatteners, sex and weight group were included into completely randomized model. 


\section{Results and Discussion}

Average pre-slaughter body mass of SBM and $\mathrm{M}$ animals was $103.67 \pm 1.30$ and $103.53 \pm 1.21 \mathrm{~kg}(\mathrm{P}=0.937)$ and age 339.08 and 331.35 days $(\mathrm{P}=0.506)$. Average pre-slaughter body mass of the first weight group $\left(\mathrm{G}_{1}\right)$ was $97.97 \pm 1.36$ and of the second $\left(\mathrm{G}_{2}\right)$ 109.41 \pm 1.14 kilograms. Statistically significant differences (Table 1) were established between $\mathrm{G}_{1}$ and $\mathrm{G}_{2}$ in both breeds, but not between the same weight groups of different groups. The variation of the mass of warm and cold carcass sides was under the influence of pre-slaughter body mass $(\mathrm{P}<.0001)$. Average daily gain from birth to slaughter (LDG) was $315 \mathrm{~g}$ and it varied between groups of animals slaughtered at different body mass $(\mathrm{G})$. The mass of warm carcass sides increased in average by $257 \mathrm{~g} / \mathrm{day}$. The share of muscle tissue established by dissection (MEAD) and based on the rulebook (MEAR) showed no variations $(\mathrm{P}>0.05)$ under the influence of breed, sex and weight group.

In present study, average daily gain from birth to the end of fattening was lower and there was no difference between SBM and M (307 and $316 \mathrm{~g}, \mathrm{P}>0.05)$. Average daily gain of Moravka breed in this study was similar to results obtained by Belić and Ognjanovic (1958, 319g=100,87 kg /316 days), but significantly lower than the value established for Resavka breed by Simović (1957, over $370 \mathrm{~g}$ ).

Table 1. Statistical significance of the effects included in the model

\begin{tabular}{|l|c|c|c|c|c|}
\hline \multirow{2}{*}{ Trait $^{1)}$} & \multirow{2}{*}{ Mean $\pm \mathrm{SD}$} & \multicolumn{4}{|c|}{ Significance of the effect (Pr>F) } \\
\cline { 3 - 6 } & & $\mathrm{B}($ Breed) & $\mathrm{S}($ Sex) & $\mathrm{G}$ (Group) & $\mathrm{B}^{*} \mathrm{G}$ \\
\hline AS,days & $334.95 \pm 34.80$ & 0.5055 & 0.8454 & 0.7990 & 0.9502 \\
\hline PSBM, kg & $104.57 \pm 8.25$ & 0.9367 & 0.0896 & $<.0001$ & 0.0397 \\
\hline MWCS, kg & $85.31 \pm 8.15$ & 0.2019 & 0.2029 & $<.0001$ & 0.0121 \\
\hline MCCS, kg & $83.19 \pm 8.13$ & 0.2110 & 0.2095 & $<.0001$ & 0.0141 \\
\hline LDG, kg & $0.315 \pm 0.035$ & 0.4051 & 0.3548 & 0.0016 & 0.1344 \\
\hline ADG, kg & $0.257 \pm 0.033$ & 0.1165 & 0.4694 & 0.0018 & 0.0590 \\
\hline MEAD, \% & $31.30 \pm 3.44$ & 0.3328 & 0.8692 & 0.4990 & 0.4357 \\
\hline MEAR,\% & $29.82 \pm 1.12$ & 0.4629 & 0.4511 & 0.1854 & 0.6173 \\
\hline
\end{tabular}

1) AS-Age at slaughter; PSBM - Pre-slaughter body mass; MWCS - Mass of warm carcass sides; MCCS - Mass of cold carcass sides; LDG - Daily gain per day of life; ADG - Average daily gain of warm carcass sides; MEAD - Share of muscle tissue determined by dissection (EC, 3127/94); MEAR - Share of muscle tissue determined according to Rulebook (1985)

Of total thigh/leg mass, share of the muscle tissue was 44.92 to $48.57 \%$ (Table 2), but without statistical significance in the variation of this value. The lowest share of skin and subcutaneous fat tissue was established in the thigh/leg of animals from the first group $\left(\mathrm{G}_{1 \mathrm{SBM}}\right)(37.14 \%)$ and the greatest in the second group $\left(\mathrm{G}_{2 \mathrm{M}}\right)(41.84 \%)$. Established difference in mean values was statistically significant $(\mathrm{P}<0.01)$. 
Table 2. The effect of pre-slaughter body mass $\left(G_{1}\right.$ and $\left.G_{2}\right)$ on distribution of tissues in four major carcass side parts of Swallow-Belly Mangalitsa and Moravka pigs

\begin{tabular}{|c|c|c|c|c|c|}
\hline \multirow[t]{2}{*}{ Part } & \multirow{2}{*}{$\begin{array}{l}\text { Share of } \\
\text { tissues in } \\
\text { the mass of } \\
\text { the part, } \%\end{array}$} & \multicolumn{2}{|c|}{$\begin{array}{c}\text { Swallow-Belly Mangalitsa - SBM } \\
(\text { LSMean } \pm \text { SE) }\end{array}$} & \multicolumn{2}{|c|}{$\begin{array}{l}\text { Moravka - M } \\
(\text { LSMean } \pm \text { SE) }\end{array}$} \\
\hline & & $\mathrm{G}_{1 \mathrm{LM}}$ & $\mathrm{G}_{2 \mathrm{LM}}$ & $\mathrm{G}_{1 \mathrm{M}}$ & $\mathrm{G}_{2 \mathrm{M}}$ \\
\hline \multirow{4}{*}{$\begin{array}{c}(1) \\
\text { Thigh/Leg }\end{array}$} & $\mathrm{MT}^{1)}$ & $48.57 \pm 1.63$ & $46.07 \pm 1.38$ & $45.01 \pm 1.53$ & $44.92 \pm 1.24$ \\
\hline & SSFT & $37.14 \pm 1.76^{\mathrm{A}}$ & $40.89 \pm 1.50$ & $41.09 \pm 1.66$ & $41.84 \pm 1.35^{\mathrm{B}}$ \\
\hline & IMFT & $6.52 \pm 0.48$ & $5.46 \pm 0.41$ & $6.14 \pm 0.45$ & $5.94 \pm 0.37$ \\
\hline & BT & $7.77 \pm 0.28$ & $7.57 \pm 0.24$ & $7.76 \pm 0.27$ & $7.29 \pm 0.22$ \\
\hline \multirow{4}{*}{$\begin{array}{c}(2) \\
\text { Back-Loin }\end{array}$} & MT & $29.78 \pm 1.58$ & $28.79 \pm 1.35$ & $29.88 \pm 1.50$ & $28.89 \pm 1.22$ \\
\hline & SSFT & $51.36 \pm 1.63$ & $50.84 \pm 1.40$ & $50.40 \pm 1.54$ & $51.89 \pm 1.25$ \\
\hline & IMFT & $7.81 \pm 0.84$ & $8.91 \pm 0.71$ & $7.94 \pm 0.79$ & $7.82 \pm 0.64$ \\
\hline & BT & $11.04 \pm 0.65$ & $11.46 \pm 0.55$ & $11.79 \pm 0.61$ & $11.40 \pm 0.50$ \\
\hline \multirow{4}{*}{$\begin{array}{c}(3) \\
\text { Shoulder }\end{array}$} & MT & $45.78 \pm 2.62$ & $40.56 \pm 2.24$ & $41.76 \pm 2.48$ & $41.26 \pm 2.01$ \\
\hline & SSFT & $37.08 \pm 2.02^{\mathrm{A}}$ & $41.29 \pm 1.73$ & $42.00 \pm 1.91$ & $43.24 \pm 1.55^{\mathrm{B}}$ \\
\hline & IMFT & $7.03 \pm 1.82$ & $9.59 \pm 1.55$ & $7.15 \pm 1.72$ & $6.74 \pm 1.40$ \\
\hline & BT & $10.10 \pm 0.39^{a}$ & $8.56 \pm 0.33^{b}$ & $9.08 \pm 0.37$ & $8.76 \pm 0.30^{b}$ \\
\hline \multirow{4}{*}{$\begin{array}{c}(4) \\
\text { Belly-Rib }\end{array}$} & MT & $25.82 \pm 2.31$ & $26.99 \pm 1.97$ & $23.56 \pm 2.18$ & $25.58 \pm 1.77$ \\
\hline & SSFT & $54.91 \pm 2.41$ & $50.14 \pm 2.06$ & $54.60 \pm 2.28$ & $54.56 \pm 1.85$ \\
\hline & IMFT & $13.33 \pm 1.94$ & $17.59 \pm 1.66$ & $15.89 \pm 1.83$ & $14.50 \pm 1.49$ \\
\hline & BT & $5.94 \pm 0.42$ & $5.29 \pm 0.36$ & $5.95 \pm 0.39$ & $5.36 \pm 5.36$ \\
\hline \multirow[t]{4}{*}{$1+2+3+4$} & MT & $38.59 \pm 1.64$ & $36.74 \pm 1.40$ & $36.02 \pm 1.55$ & $36.27 \pm 1.26$ \\
\hline & SSFT & $44.38 \pm 1.68$ & $45.56 \pm 1.44$ & $46.49 \pm 1.59$ & $47.98 \pm 1.29$ \\
\hline & IMFT & $8.26 \pm 0.72$ & $9.40 \pm 0.61$ & $8.63 \pm 0.68$ & $8.26 \pm 0.55$ \\
\hline & BT & $8.77 \pm 0.32$ & $8.39 \pm 0.27$ & $8.78 \pm 0.30$ & $8.47 \pm 0.24$ \\
\hline
\end{tabular}

1) MT- Muscle tissue; SSFT- Skin and subcutaneous fat tissue; IMFT- Intermuscular fat tissue; BT bone tissue; A,B - significance at the level $\mathrm{P}<0.05$; a,b - significance at the level $\mathrm{P}<0.01$;

Share of bone tissue in thigh/leg of SBM and $\mathrm{M}$ animals in both weight groups was not statistically significantly different $(\mathrm{P}>0.05)$. In back-loin part of carcass sides of both breeds and both pre-slaughter weight groups, the subcutaneous fat tissue with skin was most present (from 50.40 to $51.89 \%$ ). Second in order was muscle tissue $(28.79-29.88 \%)$ and third bone tissue (11.04 $11.79 \%$ ). Similar was distribution of muscle and subcutaneous fat tissue with skin in shoulder and thigh/leg. Muscle tissue was most present in shoulder (40.56 $45.78 \%$ ) followed by subcutaneous fat tissue with skin $(37.08-43.34 \%)$. In shoulder part of Swallow-Belly Mangalitsa animals in the first weight group $\left(\mathrm{G}_{1 \mathrm{SBM}}\right)$ there was by $6.16 \%$ less subcutaneous fat tissue with skin than in the second weight group of Moravka animals $\left(\mathrm{G}_{2 \mathrm{M}}\right)$ and statistically significant difference was established $(\mathrm{P}<0.01)$. Also, the greatest share of bone tissue in shoulder was established in the group $\mathrm{G}_{1 \mathrm{SBM}}(10.10 \%)$ and it was statistically significantly higher compared to animals with higher pre-slaughter body mass SBM (8.56\%) and $M(8.76 \%)$. Distribution of tissues in belly-rib part had the following order: subcutaneous fat tissue with skin (50.14-54.91\%), muscle tissue 
(23.56-25.82\%), intermuscular fat tissue (13.33 - 17.59\%) and bone tissue (5.29$5.95 \%$ ). Pre-slaughter body mass of SBM and M had no effect on variation of the share of tissues in this carcass side part. In four major carcass side parts there was 36.02 to $38.59 \%$ of muscle tissue. Subcutaneous fat tissue, skin and intermuscular fat tissue made from 52.64 to $56.24 \%$ of the mass of thigh/leg, shoulder, back-loin and belly-rib part of the carcass side.

Table 3 presents traits which were under the influence of the fatteners' breed.

Table 3. The effect of breed on variation of the mass and share of tissues in carcass side parts

\begin{tabular}{|c|c|c|c|c|}
\hline $\begin{array}{l}\text { Carcass side } \\
\text { part }\end{array}$ & Trait & $\begin{array}{l}\text { Swallow-Belly } \\
\text { Mangalitsa } \\
\text { (LSMean } \pm \text { SE) }\end{array}$ & $\begin{array}{c}\text { Moravka } \\
(\mathrm{LSMean} \pm \mathrm{SE})\end{array}$ & $\operatorname{Pr}>|t|$ \\
\hline \multirow[t]{5}{*}{ Back-Loin } & Mass, kg & $6.545 \pm 0.161^{\mathrm{a}}$ & $7.276 \pm 0.149^{b}$ & 0.0020 \\
\hline & SSFT, kg & $3.345 \pm 0.123^{\mathrm{A}}$ & $3.700 \pm 0.114^{\mathrm{B}}$ & 0.0242 \\
\hline & $\mathrm{BT}, \mathrm{kg}$ & $0.733 \pm 0.028^{\mathrm{a}}$ & $0.837 \pm 0.026^{b}$ & 0.0100 \\
\hline & $\begin{array}{l}\text { MT- share in four } \\
\text { carcass side parts, } \%\end{array}$ & $21.35 \pm 0.55^{\mathrm{a}}$ & $23.53 \pm 0.51^{\mathrm{b}}$ & 0.0060 \\
\hline & $\begin{array}{l}\text { BT }- \text { share in four } \\
\text { carcass side parts, } \%\end{array}$ & $35.81 \pm 0.87^{\mathrm{A}}$ & $38.90 \pm 0.80^{\mathrm{B}}$ & 0.0127 \\
\hline Shoulder & $\begin{array}{l}\text { BT }- \text { share in four } \\
\text { carcass side parts, } \%\end{array}$ & $21.61 \pm 0.44^{\mathrm{a}}$ & $19.67 \pm 0.41^{\mathrm{b}}$ & 0.0026 \\
\hline 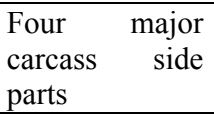 & SSFT, kg & $10.817 \pm 0.350^{\mathrm{A}}$ & $11.785 \pm 0.325^{\mathrm{B}}$ & 0.0496 \\
\hline
\end{tabular}

$\mathrm{A}, \mathrm{B}$ - significance at the level $\mathrm{P}<0.05$; $\mathrm{a}, \mathrm{b}$ - significance at the level $\mathrm{P}<0.01$; MT- Muscle tissue; SSFT- Skin and subcutaneous fat tissue; BT - bone tissue;

Moravka breed fatteners had higher average mass of back-loin carcass side part $(+0.731 \mathrm{~kg}, \mathrm{P}<0.01)$ and mass of subcutaneous fat tissue with skin $(+0,355 \mathrm{~kg}$, $\mathrm{P}<0.05)$ than Swallow-Belly Mangalitsa animals. Share of muscle tissue of this carcass side part in total mass of muscle tissue in four major carcass side parts was higher in Moravka pigs $(+2.18 \%, \mathrm{P}<0.01)$. Higher share of bone tissue in this carcass side part of Moravka animals influenced that of total mass of bone tissue in all four major carcass side parts, $38,90 \%$ was in the back-loin part. Contrary to this, of total mass of bone tissue in four major carcass side parts, $21.61 \%$ was bone tissue of shoulder, which is by $1.94 \%(\mathrm{P}<0.01)$ more than in Moravka pigs. Moravka had more skin and subcutaneous fat tissue by average $0.968 \mathrm{~kg}(\mathrm{P}<0.01)$

Male castrated animals (Table 4) shad lower average mass of thigh/leg ($0.665 \mathrm{~kg}, \mathrm{P}<0.05)$, lower mass of muscle tissue in thigh/leg $(-0.387 \mathrm{~kg}, \mathrm{P}<0.01)$ and greater share of bone tissue $(+0.54 \%, \mathrm{P}<0.05)$ compared to female animals. 
Table 4. The effect of sex of fatteners on variation of the composition of carcass side parts

\begin{tabular}{|c|c|c|c|c|}
\hline \multirow[b]{2}{*}{$\begin{array}{l}\text { Carcass side } \\
\text { part }\end{array}$} & \multirow[b]{2}{*}{ Tissue } & \multicolumn{2}{|l|}{ Sex } & \multirow[t]{2}{*}{$\operatorname{Pr}>|\mathrm{t}|$} \\
\hline & & $\begin{array}{l}\text { Males, castrated } \\
(\mathrm{LSMean} \pm \mathrm{SE})\end{array}$ & $\begin{array}{l}\text { Females } \\
(\text { LSMean } \pm \text { SE) }\end{array}$ & \\
\hline \multirow[t]{5}{*}{ Thigh/Leg } & Mass, kg & $7.979 \pm 0.174^{\mathrm{A}}$ & $8.644 \pm 0.197^{B}$ & 0.0152 \\
\hline & $\mathrm{MT}, \mathrm{kg}$ & $3.629 \pm 0.094^{\mathrm{a}}$ & $4.016 \pm 0.106^{\mathrm{b}}$ & 0.0093 \\
\hline & BT, $\%$ & $7.87 \pm 0.17^{\mathrm{A}}$ & $7.33 \pm 0.19^{\mathrm{B}}$ & 0.0396 \\
\hline & $\begin{array}{l}\text { MT - share in four carcass side } \\
\text { parts, } \%\end{array}$ & $41.46 \pm 0.69^{\mathrm{A}}$ & $43.77 \pm 0.78^{\mathrm{B}}$ & 0.0326 \\
\hline & $\begin{array}{l}\text { SSFT - share in four carcass side } \\
\text { parts, } \%\end{array}$ & $28.41 \pm 0.68^{\mathrm{A}}$ & $30.99 \pm 0.76^{\mathrm{B}}$ & 0.0154 \\
\hline Back-Loin & $\begin{array}{l}\text { SSFT - share in four carcass side } \\
\text { parts, } \%\end{array}$ & $32.82 \pm 0.66^{\mathrm{a}}$ & $30.01 \pm 0.75^{\mathrm{b}}$ & 0.0074 \\
\hline \multirow[t]{4}{*}{ Belly-Rib } & IMFT, $\mathrm{kg}$ & $0.600 \pm 0.053^{\mathrm{A}}$ & $0.787 \pm 0.060^{\mathrm{B}}$ & 0.0252 \\
\hline & $\mathrm{BT}, \mathrm{kg}$ & $0.236 \pm 0.011^{\mathrm{A}}$ & $0.268 \pm 0.012^{\mathrm{B}}$ & 0.0498 \\
\hline & $\begin{array}{l}\text { IMFT - share in four carcass side } \\
\text { parts, } \%\end{array}$ & $29.44 \pm 1.48^{\mathrm{A}}$ & $34.98 \pm 1.67^{\mathrm{B}}$ & 0.0172 \\
\hline & $\begin{array}{l}\text { BT - share in four carcass side } \\
\text { parts, } \%\end{array}$ & $11.33 \pm 0.40^{\mathrm{A}}$ & $12.70 \pm 0.45^{\mathrm{B}}$ & 0.0289 \\
\hline
\end{tabular}

$\mathrm{A}, \mathrm{B}$ - significance at the level $\mathrm{P}<0.05 ; \mathrm{a}, \mathrm{b}$ - significance at the level $\mathrm{P}<0.01$; MT- Muscle tissue; SSFT- Skin and subcutaneous fat tissue; IMFT- Intermuscular fat tissue; BT - bone tissue;

Share of muscle tissue in thigh/leg of total mass of this tissue in four major carcass side parts of male castrates was lower $(-2.31 \%, \mathrm{P}<0.05)$ compared to female animals. In belly-rib part, castrates had less intermuscular fat tissue ($0.187 \mathrm{~g}, \mathrm{P}<0.05)$ and bone tissue $(-32 \mathrm{~g}, \mathrm{P}<0.05)$ than female pigs. Intermuscular fat tissue in belly-rib part of carcass sides from castrates participated with $29.44 \%$ of the total share of this tissue in four major parts, which is by $5.54 \%(\mathrm{P}<0.05)$ less than in female pigs. The share of bone mass of belly-rib part of castrates was $11.33 \%$, and in females $12.70 \%$ of total tissue in four major carcass side parts. Lower share of bones in castrates of $1.37 \%$ was statistically significant. Skin and subcutaneous fat tissue in belly-rib part participated with $32.82 \%$ in total amount of these tissues in four major carcass side parts in castrates, which is by $2.81 \%$ more compared to females.

Housing system and nutrition influence the quantity and percentage of muscle and fat tissue in carcass sides of Black Slavonian pig (Butko et al.,2007). Animals reared in closed system had less muscle tissue $(38.50 \%)$ and more fat tissue $(43.81 \%)$ in carcass sides than animals in open system $(41.0 \%$ muscle and $40.96 \%$ fat tissue). In present study, Swallow-Belly Mangalitsa and Moravka were reared in farm conditions with free ranges and fed complete mixtures like pig genotypes used in production of meat. This influenced the research results which showed that there was no difference between fatteners of SBM and M breed in regard to content of muscle tissue in carcass sides (31.97 compared to 30.87\%). Fatteners of both breeds had less meat in carcass sides than Black Slavonian breed 
reared in closed system. Senčić et al., (2005) established that Black Slavonian pig had the most muscle tissue and least fat and bone tissue of shoulder compared to thigh/leg and back part. Contrary to this, in research including Moravka breed, it had the most muscle tissue of the back-loin part (50.40-51.89\%), which is more than the back of Black Slavonian breed (40,41\%). The effect of pre-slaughter body mass of fatteners (two groups: lighter and heavier) of Turopolj pig breed reared in open system on the share of muscle tissue (38.2 and 40.5\%) and bone tissue (10.6 and 9.7\%), but not fat tissue (34.2 and 33.8\%), was established by Djikić et al., (2004). In this research, pre-slaughter body mass had no statistically significant effect on share of muscle and bone tissue of Swallow-Belly Mangalitsa and Moravka in four major carcass side parts.

The share of meat in carcass sides of Swallow-Belly Mangalitsa was higher than established by Kralik and Petričević (2001, 28.8\%), Petrović et al. $(2009,2010,27.81 \%)$. Results of these researches showed that there was no statistical significance in the relative share of meat in carcass side parts of Swallow-Belly Mangalitsa and Moravka (31.97 to 30.87\%) reared and fed in the same way as meaty pig genotypes.

\title{
Conclusion
}

No significant differences in relative share of meat in carcass sides of investigated autochthonous breeds. Pre-slaughter body mass of Swallow-Belly Mangalitsa and Moravka influenced the variation of: SSFT in the thigh/leg and shoulder and BT in shoulder. Share of muscle tissue and bone tissue in certain carcass side parts varied between Mangalitsa and Moravka, as well as between male castrated animals and females.

\section{Acknowledgment}

Research was financed by the Ministry of Education and Science of the Republic of Serbia, project TR 31081.

\section{Udeo tkiva u polutkama svinja autohtonih rasa u zavisnosti od telesne mase i pola}

\author{
M. Petrović, Č. Radović, M. Mijatović, D. Radojković, N. Stanišić, N. Parunović
}

\section{Rezime}

Cilj ovog rada je bio da se utvrdi udeo tkiva u četiri glavna dela polutki tovljenika lasaste mangulice i moravke u zavisnosti od telesne mase pri klanju i pola grla. 
$\mathrm{Na}$ variranje mase toplih i hladnih polutki uticala je telesna masa pri klanju $(\mathrm{P}<.0001)$. U četiri glavna dela polutki bilo je od 36,02 do 38,59\% mišićnog tkiva. Potkožno masno tkivo, koža i intermuskularno masno tkivo činili su od 52,64 do 56,24\% mase buta, plećke, leđno-slabinskog i trbušno-rebarnog dela polutke. Telesna masa pri klanju grla rase LM i M je uticala na variranje potkožnog masnog tkiva i kože u butu i plećki i na koštano tkivo u plećki.

Tovljenici rase moravka imali su veću prosečnu masu ledjno-slabinskog dela polutki $(\mathrm{P}<0,01)$ i masu potkožnog masnog tkiva sa kožom $(\mathrm{P}<0,05)$ od lasaste mangulice. Udeo mišićnog tkiva ovog dela u ukupnoj masi mišićnog tkiva u četiri dela polutki, bio je veći kod grla rase moravka $(+2,18 \%, \mathrm{P}<0,01)$. Muška kastrirana grla su imala manju prosečnu masu buta $(\mathrm{P}<0,05)$, manju masu mišićnog tkiva u butu $(\mathrm{P}<0,01)$ i veći udeo koštanog tkiva $(\mathrm{P}<0,05)$ od ženskih grla. $\mathrm{U}$ trbušno-rebarnom delu, kastrati su imali manje intermuskularnog masnog tkiva $(\mathrm{P}<0,05)$ i koštanog $(\mathrm{P}<0,05)$ od ženskih grla.

\section{References}

BELIĆ J., OGNJANOVIĆ A. (1958): Poboljšanje tovne sposobnosti i klanične vrednosti moravke ukrštanjem s kornval rasom svinje. Arhiv za poljoprivredne nauke, God., XI, Sv., 34, 3-19.

BUTKO D., SENČIĆ Đ., ANTUNOVIĆ Z., ŠPERANDA M., STEINER Z. (2007): Pork carcass composition and the meat quality of the black Slavonian pig The endangered breeds in the indoor and outdoor keeping system. Poljoprivreda, $13,1,167-171$.

COMISSION REGULATION (EC) No 3127/94 of 20 December 1994 amending regulation (EC) No 2967/85 laying down detailed rules for the application of the Community scale for grading pig carcasses. Official Journal L 330, 21/12/1994, 0043-0044.

ĐIKIĆ M., SALAJPAL K., KAROLYI D., JURIĆ I., RUPIĆ V. (2004). Distribution of tissues in the carcass of turopolje pig, an autochtonous croatian breed. Acta Agriculturae Slovenica, 84, 2, 153-159.

EGERSZEGI I., RÁTKY J., SOLTI L., BRÜSSOW K-P. (2003): Mangalica - an indigenous swine breed from Hungary (Review). Arch. Tierz., Dummerstorf, 46, 3, 245-256.

KRALIK G., PETRIČEVIĆ A. (2001): Production traits of Black Slavonian pig. Proceedings: Biological diversity in animal production of Republic of Croatia, Zagreb, Hrvatska, 115-122.

PETROVIĆ M., MIJATOVIĆ M., RADOVIĆ Č., RADOJKOVIĆ D., PARUNOVIĆ N., STANIŠIĆ N. (2009): Genetic resources in pig breeding carcass and meat quality traits of moravka and mangalitsa breeds. $1^{\text {st }}$ Conference of the Balkan Network for the Animal Reproduction Biotechnology, Sofia, 14. 
PETROVIĆ M., RADOVIĆ Č., PARUNOVIĆ N., MIJATOVIĆ M., RADOJKOVIĆ D., ALEKSIĆ S., STANIŠIĆ N., POPOVAC M. (2010): Quality traits of carcass sides and meat of moravka and mangalitsa pig breeds. Biotechnology in Animal Husbandry, 26, 1-2, 21-27.

SAS INST. INC (2002-2003): The SAS System for Windows, Cary, NC.

SENČIĆ D.J., BUKVIĆ Ž., ANTUNOVIĆ M., ŠPERANDA (2005): Slaughter quality of black Slavonian pig - endangered breed and its ross-breds with swedish landrace while keeping them outdoor. Poljoprivreda, 11, 1, 43-48.

SIMOVIĆ B. (1957): Proučavanje morfoloških i fizioloških osobina svinje resavke. Doktorska disertacija, Univerzitet u Beogradu, 1-72.

WALSTRA P., MERKUS G.S. M. (1996): Procedure for assessment of the lean meat percentage as a consequence of the new EU reference dissection method in pig carcass classification. Report ID-DLO 96.014, Lelystad, 1-22.

Pravilnik o kvalitetu zaklanih svinja i kategorizaciji svinjskog mesa (1985): Službeni list SFRJ, 2, 20-30. 